\title{
Refractory EBV-Positive Diffuse Large B- Cell Lymphoma, Not Otherwise Specified
}

National Cancer Institute

\section{Source}

National Cancer Institute. Refractory EBV-Positive Diffuse Large B-Cell Lymphoma, Not

Otherwise Specified. NCI Thesaurus. Code C153332.

EBV-positive diffuse large B-cell lymphoma, not otherwise specified that is resistant to treatment. 